City University of New York (CUNY) CUNY Academic Works

\title{
A Novel Three-Way Interaction among a Fish, Algae, and a Parasitic Copepod
}

John Waldman

CUNY Queens College

\section{How does access to this work benefit you? Let us know!}

More information about this work at: https://academicworks.cuny.edu/qc_pubs/221

Discover additional works at: https://academicworks.cuny.edu

This work is made publicly available by the City University of New York (CUNY).

Contact: AcademicWorks@cuny.edu 


\section{The Scientific Naturalist}

Ecology, 98(12), 2017, pp. 3219-3220

(C) 2017 by the Ecological Society of America

\section{A novel three-way interaction among a fish, algae, and a parasitic copepod}

It was on a mid-December evening in 2015 when I looked down at the water from a high pier in Hempstead Harbor, New York, and viewed something I'd never seen before-what appeared to be fish swimming with an odd motion, not unlike fancy male guppies struggling to beat their oversized caudal fins. Though it was turning dark, I could see the fish were young Atlantic menhaden Brevoortia tyrannus and that not all, but many individuals were displaying this strange behavior.

I tried but could not catch any of the mysterious menhaden with a snag hook that evening. Two days later I lowered a hoop net off the pier and waited for a school of them to swim over it. The fish moved slowly in the chilly water but eventually I could see dark shapes against the white mesh. A quick lift and I had a dozen or so silvery menhaden flopping on the dock. The source of the mystery was instantly revealed - a number of the specimens had been dragging around streaming algal growths, some of considerable length (Fig. 1). Stranger still was the nature of the attachment of the algae - they were rooted in red tubular protuberances embedded at various locations on the fish's bodies.

I subsequently sent photos to a number of fish parasitologists and experts on menhaden along the Atlantic coast and no one had seen this occurrence. A novel phenomenon was revealed: a three-way interaction across three trophic levels, involving a fish, an invertebrate, and algae.

Between 15 and 27 December, I netted 99 specimens of the menhaden, a marine member of Clupeidae (herrings). Menhaden are a tightly schooling prey fish that filter phytoplankton and zooplankton near the surface of inshore marine waters. The red tubular structures were the visible, unsegmented portion of the adult female stage of an ectoparasitic copepod, Lernaeenicus radiates, known colloquially as the anchor worm (anchor worms are named after hook-like extensions that embed firmly in the fish's flesh). Though not directly fatal, Lernaea spp. can provoke severe inflammation and heavy incidences can lead to debilitation or secondary infection by bacteria or fungi (Purivirojkul 2012). Parasitism of fish by copepods is not unusual; nearly 30 families of Copepoda parasitize fish at during some part of their life cycle. Menhaden are commonly parasitized by anchor worms, but more often on adult specimens. However, the anchor worms seen are naked, with no attaching organisms.

The attaching algae were primarily of two species, red Polysiphonia sp. and green Enteromorpha intestinalis. Among my specimens, Polysiphonia typically grew broadly

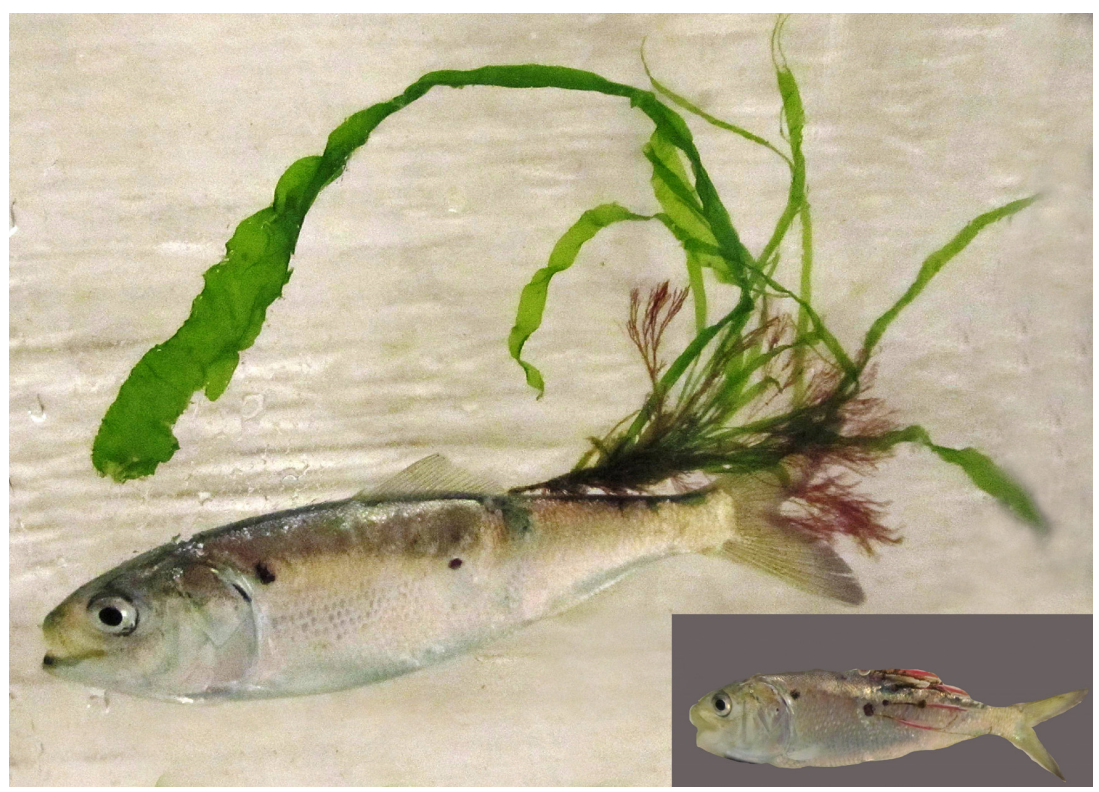

FIG. 1. Green Enteromorpha intestinalis and red Polysiphonia sp. algae attached to copepod (Lernaeenicus radiates) ectoparasite on a juvenile menhaden. Inset: Close-up of four Lernaeenicus radiates showing early algal colonization on another menhaden. [Color figure can be viewed at wileyonlinelibrary.com] 
in a short tuft, whereas Enteromorpha trailed as a lengthy streamer, to a maximum of twice the fish's length (Fig. 1). Given such vegetative adornment, I called the afflicted menhaden "saladbacks."

The menhaden in my collection ranged between 32 and $100 \mathrm{~mm}$ standard length. Of the 99 specimens, $69 \%$ were embedded by between one to four anchor worms. The parasites attached at various locations, including the fish's mouth and tongue, its fin insertions, its flanks, and the caudal peduncle. Of the individual menhaden infected with one or more anchor worms, $69 \%$ had visible algae attached to at least one of the parasites.

I surmise that the interactions among the fish, parasite, and algae had the following benefits and costs: (1) the fish "loses" in two ways, sustaining the costs of both nourishing the parasite and the hydrodynamic drag of the algae. It was obvious that menhaden bearing one or more of the parasites with attached algae needed to swim more vigorously than those individuals that were not pulling algae to keep pace with the school. (2) The parasite benefits from the nutrition derived from its host and is neutral regarding its attachment of algae. And (3) the algae gains from having an attachment site (on the parasite). The polarity of the relationship between the algae and fish is less apparent, but I speculate that the menhaden's surface-dwelling habits increase the algae's access to sunlight (averting the effect of tidal submergence for algae rooted low in the intertidal zone) and the fish school's movements and excretions increase the availability of nutrients.

The appearance of this odd occurrence in western Long Island Sound may be related to an unusual combination of the behavior of parasitized menhaden, the unusually warm weather of autumn 2015 in the New York City region, and extremely high juvenile menhaden production that year. Menhaden normally migrate south from Long Island Sound in November, though in some years I have seen some linger as late as early December. Earlier, it was found in Chesapeake Bay that juvenile menhaden parasitized by Lernaeenicus radiates may remain within their natal estuaries while unparasitized individuals migrate normally as water temperatures decline (Guthrie and Kroger 1974). October through December 2015 was the warmest $\left(3.8^{\circ} \mathrm{C}\right.$ departure) on record for New York since 1895 (NOAA National Centers for Environmental Information), which may have allowed menhaden individuals unfit for migration, such as those afflicted as described, to live weeks beyond normal for this location and in conditions that were suitable for algal attachment and growth.

The extremely high abundance of menhaden in 2015 likely played a role in the high degree of anchor worm infestation inasmuch as the parasite's reproduction should have been assisted by the ease with which hosts could be found. Menhaden schools show on the surface, and in summer and autumn 2015 I witnessed them covering acres and acres of western Long Island Sound. Such anecdotal observations were supported by an annual menhaden trawl-survey abundance index that in 2015 reached a 31-yr record peak in Long Island Sound (ASMFC 2016). Survival of parasitized menhaden individuals into winter together with elaboration of the attaching algae may have been assisted by the completed outmigration of their primary autumn predator, striped bass Morone saxatilis, which were no longer visible preying on menhaden schools as they had been several weeks earlier.

Menhaden bearing algae-covered anchor worms were also seen and captured at another site $2 \mathrm{~km}$ distant in Hempstead Harbor, and I suspect the phenomenon may have been widespread in western Long Island Sound. Also, the entirety of a warm winter of 2015-2016 may have allowed menhaden to remain in Long Island Sound rather than migrating. In April 2016 I viewed a large school of the same cohort of menhaden in the marina on one side of the pier on which I first observed them, but was unable to collect any. Nonetheless, I could clearly see that some were saladbacks but that afflicted individuals were able to swim more easily than before, given their larger size. I visually estimated a parasite-algae infection rate at that time at $<10 \%$. However, it is not clear if the afflicted individuals were survivors of ongoing parasitic infestations from the previous year or were newly parasitized. It is likely that winter survivors afflicted with the algae-coated copepods would become vulnerable in springtime to returning predators and that this could contribute to the lower infection rate.

Three-way and higher evolutionary interactions among organisms have received increasing attention in evolutionary ecology (e.g., Roopin et al. 2011, Biere and Bennett 2013, Bairey et al. 2016). However, these describe wellestablished, ongoing relationships. My observations suggest that a conventional two-way interaction may become a novel three-way interaction under unusual circumstances. These interactions may be ephemeral, lasting as long as the required conditions allow. However, it is also possible that with the substantial ecological shifts anticipated from advancing climate change and associated effects, surprising facultative interactions among various organisms may become more frequent and longer lasting.

\section{JOHN WALDMAN ID}

Manuscript received 10 March 2017; revised 25 July 2017; accepted 26 July 2017. Corresponding Editor: John Pastor.

Biology Department, Queens College, 65-30 Kissena Boulevard, Queens, New York 11367 USA.

E-mail: john.waldman@qc.cuny.edu

Literature Citations are available as supporting information to the online version of this article at: http://onlinelibrary.wiley. com/doi/10.1002/ecy.1993/suppinfo 